\title{
Permeability changes in heartwood of Picea abies and Abies alba induced by incubation with Physisporinus vitreus*
}

\author{
Francis W.M.R. Schwarze ${ }^{1,2, \star *}$, Helge \\ Landmesser ${ }^{1,2}$, Bruno Zgraggen ${ }^{1}$ and Markus \\ Heeb $^{1}$ \\ ${ }^{1}$ Wood Laboratory, Swiss Federal Laboratories for \\ Materials Testing and Research (EMPA), St. Gallen, \\ Switzerland \\ 2 Institut für Forstbotanik und Baumphysiologie, Albert- \\ Ludwigs-Universität Freiburg, Freiburg i.Br., Germany \\ ${ }^{\star *}$ Corresponding author. \\ Wood Laboratory, Swiss Federal Laboratories for Materials \\ Testing and Research (EMPA), Lerchenfeldstr. 5, 9014 St. \\ Gallen, Switzerland \\ E-mail: francis.schwarze@empa.ch
}

\begin{abstract}
The present study shows that isolates of $P$. vitreus have an extraordinary capacity to induce substantial permeability changes in heartwood of $P$. abies without causing significant losses in impact bending strength. The degradation of pit membranes by $P$. vitreus is an important aspect that could also have significant benefits in wood protection processes. Further studies are currently in progress with the objective of optimising the uniformity of wood colonisation and duration of incubation, so as to improve the permeability of water-borne wood preservatives or hydrophobic substances applied by brushing, dipping and impregnation.
\end{abstract}

Keywords: Abies alba; heartwood; Physisporinus vitreus; Picea abies; wood permeability.

\section{Introduction}

The permeability of conifer wood is enhanced by biodegradation of pit membranes, which usually occurs in the course of bacterial activity in water-stored logs (Schmidt and Liese 1994). Permeability of sapwood has been increased after such a treatment and as a consequence the uptake of preservatives was improved (Bauch et al. 1970; Johnson 1979; Schmidt and Liese 1994). Treatment of wood with enzymes that degrade the principal constituents of the pit membranes (pectin, hemicelluloses and celluloses) is also promising (Nicholas and Thomas 1968; Bauch et al. 1970; Sharma and Kumar 1979). More recent findings indicate that the most effective enzymes are hydrolases with a broad spectrum of cellulolytic and hemicellulolytic activity when finely ground Picea abies wood was the substrate (Militz 1993a,b). It was, however, also noted that the practical

${ }^{*}$ Dedicated to Prof. Dr. (Dr. hc mult.) Walter Liese, to mark his 80th birthday. importance of enzymes in this context is limited: their diffusion into wood is slow and the extractives adhering to aspirated pits have inhibitory effects (Militz 1993a,b). Rosner et al. (1998) demonstrated that basidiomycetes are capable of colonising sapwood and heartwood and can improve the permeability. A major disadvantage is that fungi also weaken the wood by degrading the secondary walls as well as the pit membranes (Tucker et al. 1998). The white rot fungus Physisporinus vitreus is an exception in this regard; it preferentially degrades the pit membranes of bordered pits in the heartwood of conifers under controlled conditions, and causes only negligible mass losses (Schwarze and Landmesser 2000). This fungus is, however, capable of strongly degrading water-saturated timber in cooling towers (Schmidt et al. 1996, 1997).

The objective of the present study was to investigate whether $P$. vitreus can significantly enhance the permeability of conifer heartwood without inducing significant strength losses. If this approach is successful, several processes for wood modification and finishing could be significantly improved. The improved permeability of waterborne solvents into conifer wood is one useful application.

\section{Materials and methods}

Specimens from the heartwood of living 40-50-year-old trees of Abies alba Mill. and Picea abies Karst were incubated with two isolates of $P$. vitreus and then assessed for quantitative and spatial alterations in their water uptake and impact bending strength. Wood specimens of two different dimensions, but cut exactly the same in the radial and tangential planes, were investigated: (1) $100 \mathrm{~mm}$ (longitudinal) $\times 10 \mathrm{~mm}$ (tangential) $\times 15 \mathrm{~mm}$ (radial) $\left(15 \mathrm{~cm}^{3}\right)$; and (2) $100 \mathrm{~mm}$ (longitudinal) $\times 25 \mathrm{~mm}$ (tangential) $\times 15 \mathrm{~mm}$ (radial) $\left(37.5 \mathrm{~cm}^{3}\right)$. A total of 448 test specimens were prepared according to European standard EN 113 (1997), comprising 16 specimens for each treatment and incubation period. Mass loss and water uptake were measured for each specimen before and after incubation. Before water uptake measurements, wood specimens were dried at $103^{\circ} \mathrm{C}$ for 18-24 $\mathrm{h}$ and then cooled in a desiccator and weighed. Strength tests were performed only with the smaller specimens, and microscopy was carried out exclusively on the larger specimens.

\section{Selection of heartwood specimens}

The water uptake of the blocks was measured (in $\mathrm{kg} \mathrm{m}^{-3}$ ) according to EN 113 before incubation. Based on the results, only specimens that showed the typical water uptake for heartwood of each of the two species were selected. Wood specimens with atypical water uptake were rejected. This ensured that all specimens contained a high proportion of heartwood. To ensure that water was taken up via the tangential and radial surfaces only, the end grain of each dried and weighed specimen was first sealed with soft silicone grease and firmly fixed 


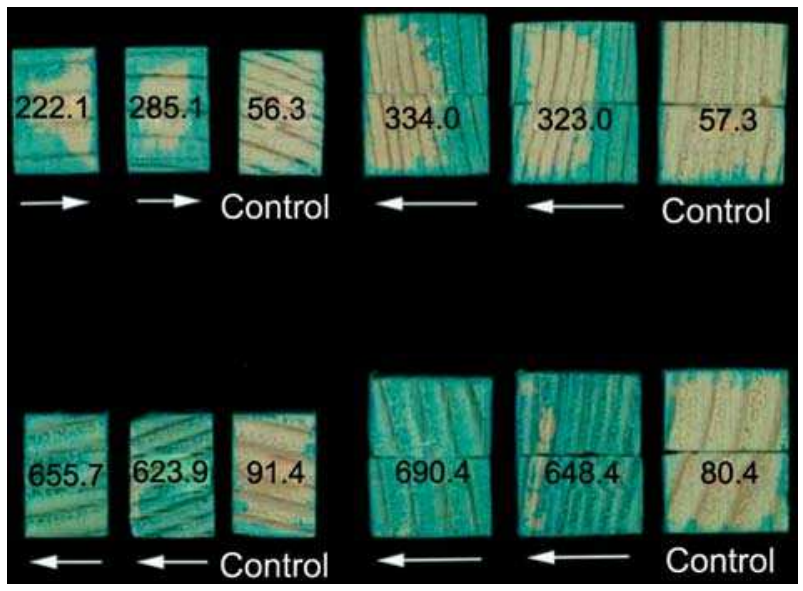

Figure 1 Heartwood specimens of Picea abies (top) and Abies alba (bottom) impregnated with a $0.1 \%$ aqueous solution of Neolan Glaucin E-A using vacuum treatment after 6-week incubation with Physisporinus vitreus (left, $15 \mathrm{~cm}^{3}$; right, $37.5 \mathrm{~cm}^{3}$ ). Numbers refer to radial and tangential uptake of water in $\mathrm{kg} \mathrm{m}^{-3}$. In comparison to weakly stained controls, cross-sections of incubated $P$. abies specimens are moderately stained and those of $A$. alba are strongly stained. Arrows indicate the direction from which wood samples were colonised by hyphae.

between metal mounts to prevent the formation of cracks and shakes. Retention of water taken up via the tangential and radial surfaces was then measured by immersing the blocks in distilled water at reduced pressure (7 mbar) for $20 \mathrm{~min}$ in a vacuum desiccator according to EN 113. Then the vacuum vessel was brought back to atmospheric pressure and the specimens were left for a further $120 \mathrm{~min}$ in water before re-weighing (Figure 1).

\section{Incubation of wood specimens}

Before incubation, the blocks were sterilised with ethylene oxide for approximately $1 \mathrm{~h}$. Incubation was carried out with two isolates of Physisporinus vitreus (EMPA 642 and EMPA 643) in Kolle flasks according to EN 113. The flasks were incubated in a random array at $22 \pm 1^{\circ} \mathrm{C}$ and $75 \pm 5 \% \mathrm{RH}$ for 6,12 and 18 weeks. After incubation, the wood blocks were dried for $48 \mathrm{~h}$ at $30^{\circ} \mathrm{C}$ and permeability changes were measured. To evaluate qualitative changes in uptake and distribution of the synthetic organic textile dye Neolan Glaucin E-A (Ciba Geigy), the end grain of each block was sealed with silicone grease as described above and the wood specimens were then impregnated with a $0.1 \%$ aqueous solution of the dye according to EN 113. After impregnation, incubated wood blocks were dried at $103^{\circ} \mathrm{C}$ for $18-24 \mathrm{~h}$ and then cooled in a desiccator and weighed for measurement of mass loss. The smaller wood specimens $\left(15 \mathrm{~cm}^{3}\right)$ were preconditioned in an incubator at $20^{\circ} \mathrm{C}$ and $65 \% \mathrm{RH}$ for 4 weeks. Their impact bending strength, $A_{\mathrm{w}}\left(\mathrm{kJ} \mathrm{m}^{-2}\right)$, was measured in the tangential direction using a Zwick pendulum impact testing machine in accordance with DIN standard 52189 (1981). For statistical evaluation of differences between control and incubated blocks of each tree species for water retention and impact bending strength, $t$-tests $(P<0.05-P<0.001)$ were performed using Origin 7.5 (Microcal Software Inc.).

\section{Electron microscopy}

Radial longitudinal specimens were extracted from stained and unstained regions of the larger $\left(37.5 \mathrm{~cm}^{3}\right)$ incubated wood blocks. These were then dried in a vacuum oven at $40^{\circ} \mathrm{C}$ and 10 mbar for $12 \mathrm{~h}$, glued on a specimen holder using carbonadhesive and sputtered with a platinum layer of approximately
$10 \mathrm{~nm}$ for investigation using a field-emission SEM (Jeol 6300F) at an acceleration voltage of $5 \mathrm{kV}$ and working distance of $24 \mathrm{~mm}$.

\section{Results and discussion}

The mass losses in heartwood of $P$. abies and $A$. alba were negligible after 6 -week incubation ( $<1 \%$, Table 1$)$. After 12 and 18 weeks, there were significant differences between the mass losses in $P$. abies and $A$. alba $(\mathrm{P}<0.05)$. Only after 6-week incubation, as the mass losses induced by both $P$. vitreus isolates were slight, was the wood permeability increased, as manifest by the increase in water uptake in the test blocks to approximately $300-400 \mathrm{~kg} \mathrm{~m}^{-3}$ in $P$. abies and $400-680 \mathrm{~kg} / \mathrm{m}^{-3}$ in A. alba (Table 1). The differences before and after incubation of the specimens were highly significant $(\mathrm{P}<$ 0.001). The two $P$. vitreus isolates showed no significant differences in their effect on permeability. Conspicuous qualitative changes in permeability were also apparent from the uptake of the bluish dye Neolan Glaucin E-A. Uptake of the dye by $A$. alba test blocks incubated with $P$. vitreus was homogeneous on visual inspection, but the homogeneity was less pronounced in corresponding $P$. abies blocks.

FE-SEM studies revealed that uptake of Neolan Glaucin E-A was attributable to preferential degradation of pit membranes (Figures 2 and 3). Complete or partial hydrolysis of bordered pits and crossfield pits was apparent in regions stained with Neolan Glaucin E-A. Unstained regions of pit membranes remained intact (Figure 3). Hyphae entered the pit chamber via apertures, and membranes were subsequently degraded (Figures 2 and 3). Degradation commenced from the thickened central part of the membrane (torus). Calcium oxalate crystals were regularly observed on hyphae. In wood of $A$. alba, crystals accumulations were often apparent within bordered pits in close proximity to hyphae (Figure 3). Production of polygalacturonase (PG) and hydrolysis of bordered pit membranes during incipient decay has been described in detail (Green et al. 1991, 1995a,b; Green and Clause 1999). A key factor for pectin hydrolysis by plant pathogens has been shown to be fungal production of oxalic acid, which lowers the $\mathrm{pH}$ of the substrate and chelates calcium ions. Production of oxalic acid may serve a similar role for $P$. vitreus isolates during incipient wood decay.

Crossfield pits of the xylem ray parenchyma also showed signs of extensive degradation. In decayed wood specimens of $A$. alba, degradation of taxodioid pit membranes was found throughout the stained wood regions. In contrast, degradation of piceoid pit membranes in $P$. abies was more localised and was restricted to cells near the outer surfaces of the specimens. Previous studies have demonstrated that most brown- and white-rot fungi have the capacity to hydrolyse the pectin in pit membranes during incipient decay, which facilitates colonisation (Cowling 1961; Wilcox 1968; Green and Clausen 1999; Schwarze and Landmesser 2000; Schwarze et al. 2004).

The impact bending strength of incubated $P$. abies wood specimens was not significantly reduced in 
Table 1 Mass loss, water uptake and strength loss in heartwood specimens of Picea abies and Abies alba after 6-, 12- and 18-week incubation with two isolates of Physisporinus vitreus.

\begin{tabular}{|c|c|c|c|c|c|c|c|c|c|}
\hline \multirow[t]{2}{*}{ Sample } & \multicolumn{3}{|c|}{ Mass loss (g) } & \multicolumn{3}{|c|}{ Water uptake $\left(\mathrm{kg} \mathrm{m}^{-3}\right)$ (before and after incubation) } & \multicolumn{3}{|c|}{ Strength $\left(\mathrm{kJ} \mathrm{m}^{-2}\right)$} \\
\hline & 6 weeks & 12 weeks & 18 weeks & 6 weeks & 12 weeks & 18 weeks & 6 weeks & 12 weeks & 18 weeks \\
\hline \multicolumn{10}{|l|}{ P. abies } \\
\hline Control, $15 \mathrm{~cm}^{3}$ & - & & & & & & $25.7 \pm 4.05$ & & \\
\hline EMPA $642,15 \mathrm{~cm}^{3}$ & $0.9 \pm 0.35^{\mathrm{NS}}$ & $6.50 \pm 2.30^{\star \star \star}$ & $10.7 \pm 4.26^{\star \star \star}$ & $\begin{array}{l}174.8 \pm 66.15 \\
418.7 \pm 176.64^{\star \star \star}\end{array}$ & $\begin{array}{l}170.60 \pm 69.20 \\
598.30 \pm 167.20^{\star \star \star}\end{array}$ & $\begin{array}{c}55.6 \pm 64.90 \\
738.80 \pm 156.18^{\star \star \star}\end{array}$ & $22.7 \pm 2.00^{\mathrm{NS}}$ & $13.0 \pm 3.26^{\star \star \star}$ & $9.9 \pm 4.77^{\text {** }}$ \\
\hline EMPA $643,15 \mathrm{~cm}^{3}$ & $0.8 \pm 0.29^{\mathrm{NS}}$ & $4.2 \pm 0.97^{\star \star \star}$ & $8.1 \pm 3.78^{\star}$ & $\begin{array}{l}185.30 \pm 70.66 \\
378.90 \pm 160.32^{\star \star \star}\end{array}$ & $\begin{array}{l}328.90 \pm 188.50 \\
449.50 \pm 154.85^{\star \star \star}\end{array}$ & $\begin{array}{c}150.4 \pm 62.60 \\
760.10 \pm 86.18^{\star \star \star}\end{array}$ & $23.2 \pm 3.57^{\mathrm{Ns}}$ & $16.3 \pm 3.26^{\star \star \star}$ & $11.0 \pm 2.90^{\star \star \star}$ \\
\hline EMPA $642,37.5 \mathrm{~cm}^{3}$ & $0.8 \pm 0.24^{\mathrm{NS}}$ & $5.30 \pm 1.37^{\star * \star}$ & $7.0 \pm 2.41^{\star \star *}$ & $\begin{array}{c}34.7 \pm 44.77 \\
327.0 \pm 75.22^{\star \star \star}\end{array}$ & $\begin{array}{l}50.40 \pm 70.71 \\
650.3 \pm 113.78^{\star \star \star}\end{array}$ & $\begin{array}{c}69.8 \pm 39.4 \\
782.20 \pm 59.87^{\star \star \star}\end{array}$ & - & - & - \\
\hline EMPA $643,37.5 \mathrm{~cm}^{3}$ & $0.8 \pm 0.24^{\mathrm{NS}}$ & $3.9 \pm 1.24^{\star \star \star}$ & $6.3 \pm 3.19^{\star}$ & $\begin{array}{c}98.90 \pm 40.96 \\
375.80 \pm 83.78^{\star \star \star}\end{array}$ & $\begin{array}{c}54.2 \pm 64.30 \\
571.90 \pm 155.09^{\star \star \star}\end{array}$ & $\begin{array}{c}53.20 \pm 58.80 \\
772.30 \pm 56.15^{\star \star \star}\end{array}$ & - & - & - \\
\hline $\begin{array}{l}\text { A. alba } \\
\text { Control }\end{array}$ & - & & & 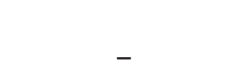 & & & $25.7 \pm 4.13$ & & \\
\hline EMPA $642,15 \mathrm{~cm}^{3}$ & $0.9 \pm 0.36$ & $3.41 \pm 1.25$ & $5.8 \pm 2.70$ & $\begin{aligned} 162.80 & \pm 70.71 \\
660.7 & \pm 64.04^{\star \star \star}\end{aligned}$ & $\begin{array}{l}174.10 \pm 70.71 \\
672.9 \pm 174.10^{\star \star \star}\end{array}$ & $\begin{array}{l}135.90 \pm 49.30 \\
819.8 \pm 70.71^{\star \star *}\end{array}$ & $17.6 \pm 2.00^{\star *}$ & $18.0 \pm 3.18^{\star \star \star}$ & $14.6 \pm 2.81^{\star \star \star}$ \\
\hline EMPA $643,15 \mathrm{~cm}^{3}$ & $0.7 \pm 0.24$ & $1.60 .8 \pm 1.51$ & $5.0 \pm 3.48$ & $\begin{array}{l}332.60 \pm 75.48 \\
536.40 \pm 120.30^{\star \star \star}\end{array}$ & $\begin{array}{l}219.3 \pm 158.30 \\
532.7 \pm 112.26^{\star \star \star}\end{array}$ & $\begin{array}{c}157.9 \pm 76.60 \\
754.20 \pm 51.84^{\star \star \star}\end{array}$ & $20.5 \pm 3.57^{\star}$ & $17.3 \pm 2.16^{\star \star \star}$ & $11.0 \pm 2.90^{\star \star \star}$ \\
\hline EMPA $642,37.5 \mathrm{~cm}^{3}$ & $0.7 \pm 0.24$ & $1.40 \pm 1.39$ & $3.2 \pm 2.70$ & $\begin{array}{l}168.10 \pm 37.77 \\
647.70 \pm 88.41^{\star * \star}\end{array}$ & $\begin{array}{l}168.10 \pm 37.80 \\
654.7 \pm 75.18^{\star \star \star}\end{array}$ & $\begin{array}{l}285.40 \pm 46.30 \\
758.90 \pm 47.82^{\star \star \star}\end{array}$ & - & - & - \\
\hline EMPA $643,37.5 \mathrm{~cm}^{3}$ & $0.7 \pm 0.35$ & $1.1 \pm 0.96$ & $3.50 \pm 3.37$ & $\begin{array}{l}165.60 \pm 40.89 \\
631.0 \pm 87.25^{\star \star \star}\end{array}$ & $\begin{array}{l}173.7 \pm 36.80 \\
664.6 \pm 89.86^{\star \star \star}\end{array}$ & $\begin{array}{l}303.60 \pm 43.90 \\
769.40 \pm 39.85^{\star \star \star}\end{array}$ & - & - & - \\
\hline
\end{tabular}

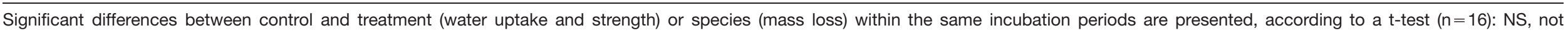
significant; ${ }^{*} \mathrm{P}<0.05 ;{ }^{* \star} \mathrm{P}<0.01 ;{ }^{* \star *} \mathrm{P}<0.001$. 

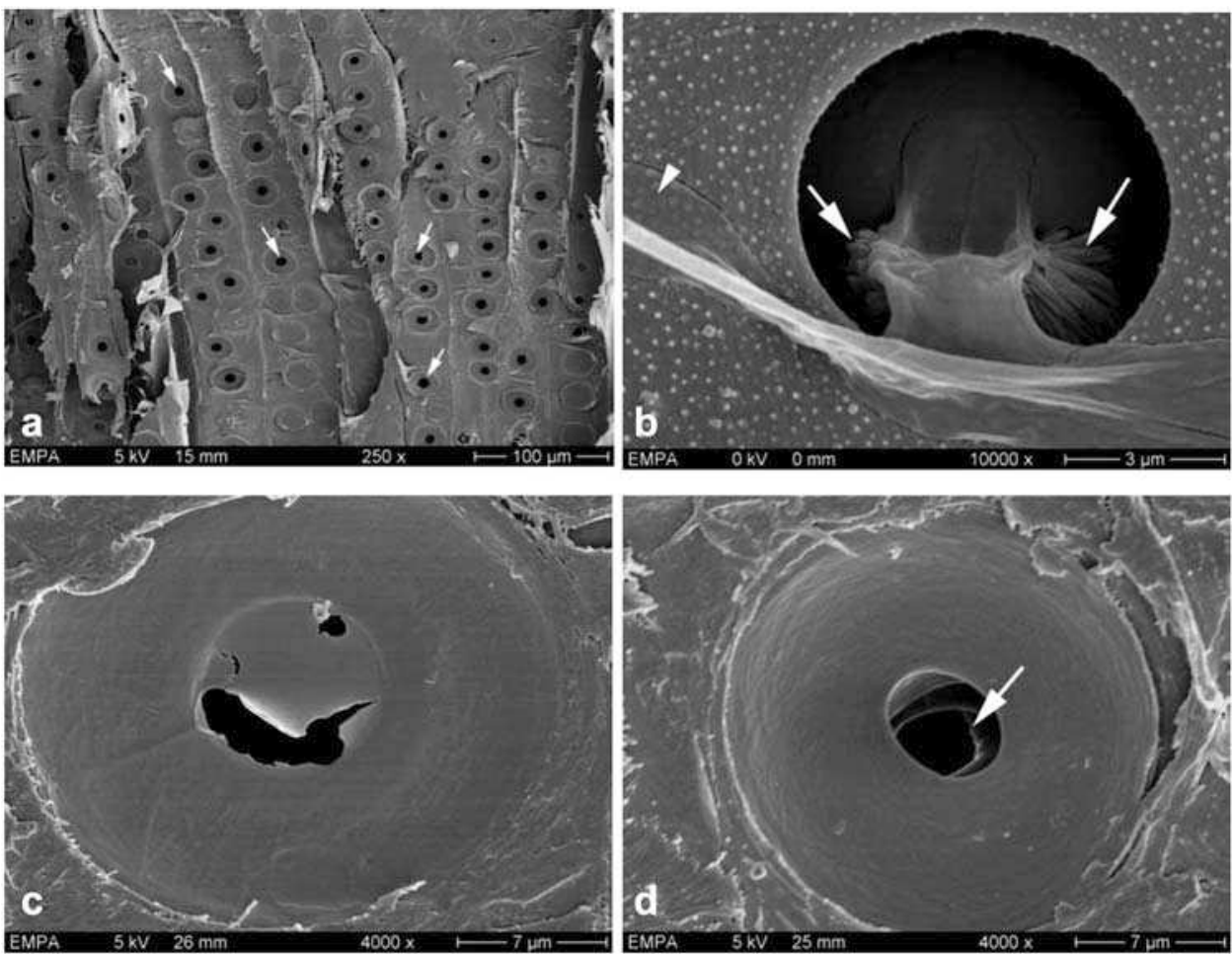

Figure 2 Scanning electron micrographs (5 kV) showing bordered pits (a-d) in Picea abies and Abies alba after 6-week incubation with Physisporinus vitreus. Hyphae entered the bordered pits via the aperture and degraded the torus; lysis of the warty layer (pointer) and calcium oxalate crystals (arrows) occurred in close proximity to hyphae within bordered pit chambers (b). After 12 weeks, most bordered pits showed partial to complete dissolution (c,d) of pit membranes, so that both pit apertures in pit pairs were occasionally exposed (arrow).
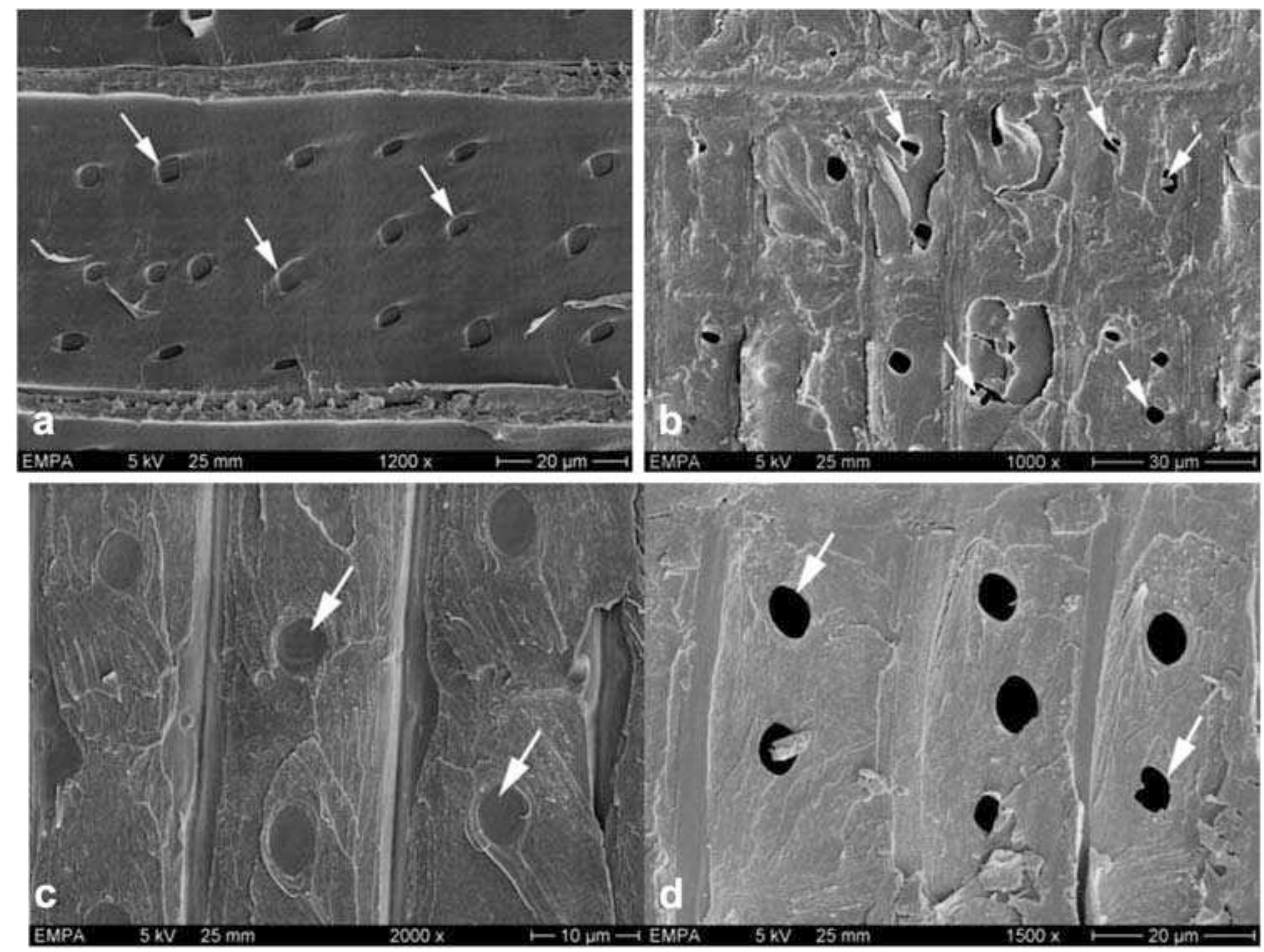

Figure 3 Scanning electron micrographs showing crossfield pits in sound and degraded heartwood of Picea abies (a,b) and Abies alba (c,d), respectively. After 6-week incubation with Physisporinus vitreus, some crossfield pits showed partial dissolution (b; arrows) in $P$. abies, whereas most pit membranes of $A$. alba were completely degraded (d; arrows). 
comparison to controls after 6 weeks, whereas there was a significant reduction in A. alba specimens (EMPA 642, $\mathrm{P}<0.01$; EMPA 643, $\mathrm{P}<0.05$; Table 1). After 12 and 18 weeks, wood strength was significantly lower in all cases in comparison to the controls $(\mathrm{P}<0.001)$.

Colonisation of wood specimens of $A$. alba and $P$. abies by $P$. vitreus was more homogeneous when they were incubated with their tangential surfaces, rather than their radial surfaces, in contact with the mycelium. The latter orientation was used for the smaller specimens, to allow them to rest on their broader (radial) surfaces. The radial surfaces of wood specimens are relatively resistant to colonisation by fungal hyphae (Kleist and Seehann 1997; Schwarze et al. 2004). Thus, a more rapid hyphal growth in the radial than tangential direction resulted in a higher increase of water uptake in larger wood specimens irrespective of the wood species. In wood specimens of $A$. alba, water uptake was also facilitated by homogenous degradation of the large taxodioid pit membranes in the xylem ray parenchyma. The results appear to suggest that $P$. vitreus colonises wood of $A$. alba more rapidly, but on the basis of losses in mass, it seems to show a preference for degrading heartwood of $P$. abies.

Although permeability increased with incubation time, significant strength losses were recorded after 12 and 18 weeks. The potentially disadvantageous strength loss in $A$. alba appears to be correlated with a more intense colonisation by $P$. vitreus, which could be mitigated simply by using shorter incubation periods and higher growth temperatures.

\section{Acknowledgements}

We would like to thank the Fond zur Förderung der Wald- und Holzforschung (FFWH), Bern, for partly funding these studies (Projektnumbers 2005.01 and 2004.16). A German patent has been issued (No. 102005002 366.5) and a European application (No. 05027812.6) has been submitted regarding the use of $P$. vitreus to increase the permeability of conifer heartwood. The authors wish to thank E. Strub for technical assistance with FEREM and Dr. D. Lonsdale for comments on the paper.

\section{References}

Bauch, J., Liese, W., Berndt, H. (1970) Biological investigations for the improvement of the permeability of softwoods. Holzforschung 24:199-205.

Cowling, E.B. (1961) Comparative biochemistry of the decay of sweetgum sapwood by white-rot and brown-rot fungi. WOTB-1258. USDA Forest Service, Washington, DC.

DIN standard 52189 (1981) Testing of wood; Impact bending test; Determination of impact bending strength.

European standard (1997) EN 113. Wood preservatives - test method for determining the protective effectiveness against wood destroying basidiomycetes. Determination of toxic values.
Green, F., Clausen, C.A. (1999) Production of polygalacturonase and increase of longitudinal gas permeability in southern pine by brown-rot and white-rot fungi. Holzforschung 53: 563-568.

Green, F., Larsen, M.J., Winandy, J.E., Highley, T.L. (1991) Role of oxalic acid in incipient brown-rot decay. Mater. Organismen 26:191-213.

Green, F., Tschernitz, J., Kuster, T.A., Highley, T.L. (1995a) Hydrolysis of bordered pits during colonization of conifers by brown-rot decay. Document No. IRG/WP/95-10103. International Research Group on Wood Protection, Stockholm, Sweden.

Green, F., Clausen, C.A., Kuster, T.A., Highley, T.L. (1995b) Induction of polygalacturonase and the formation of oxalic acid by pectin in brown-rot fungi. World J. Microbiol. Biotechnol. 11:519-524.

Johnson, B.R. (1979) Permeability changes induced in three western conifers by selective bacterial inoculation. Wood Fibre 11:10-21.

Kleist, G., Seehann, G. (1997) Colonization patterns and topochemical aspects of sap streak caused by Stereum sanguinolentum in Norway spruce. Eur. J. For. Pathol. 27:351-361.

Militz, H. (1993a) Der Einfluss enzymatischer Behandlungen auf die Tränkbarkeit kleiner Fichtenproben. Holz Roh Werkst. 51:135-142.

Militz, H. (1993b) Der Einfluss enzymatischer Behandlungen von Fichtenrund- und Schnittholz zur Verbesserung der Tränkbarkeit. Holz Roh Werkst. 51:339-346.

Nicholas, D.D., Thomas, R.J. (1968) The influence of enzymes on the structure and permeability of loblolly pine. Am. WoodPreserv. Assoc. Proc. 64:70-76.

Rosner, B., Messner, K., Tucker, E., Bruce, A. (1998) Improve preservative penetration of spruce after pre-treatment with selected fungi. I. Fungal pre-treatment of pole sections. Document No. 98-40117. International Research Group on Wood Protection, Stockholm, Sweden.

Schmidt, O., Liese, W. (1994). Occurrence and significance of bacteria in wood. Holzforschung 48:271-277.

Schmidt, O., Liese, W., Moreth-Kebernik, U. (1996) Decay of timber in a water cooling tower by the basidiomycete Physisporinus vitreus. Mater. Organismen 30:161-177.

Schmidt, O., Schmitt, U., Moreth, U., Potsch, T. (1997) Wood decay by the white-rotting basidiomycete Physisporinus vitreus. Holzforschung 51:193-200.

Schwarze, F.W.M.R., Landmesser, H. (2000) Preferential degradation of pit membranes within tracheids by the basidiomycete Physisporinus vitreus. Holzforschung 54:461-462.

Schwarze, F.W.M.R., Engels, J., Mattheck, C. (2004) Fungal strategies of wood decay in trees. 2nd ed. Springer Verlag, Heidelberg. 218 pp.

Sharma, M., Kumar, S. (1979) Degradation of wood pectin by micro-organisms. Int. J. Wood Preserv. 1:87-90.

Tucker, E., Bruce, A., Staines, H.J., Rosner, B., Messner, K. (1998). Improve preservative penetration of spruce after pretreatment with selected fungi. II. Creosote treatment, analysis and strength testing. Document No. 98-40106. International Research Group on Wood Protection, Stockholm, Sweden.

Wilcox, W.W. (1968) Changes in the microstructure through progressive stages of decay. FLP-RP-70. US Department of Agriculture, Forest Service, Forest Products Laboratory, Madison, WI.

Received January 9, 2006. Accepted March 13, 2006. 